\title{
Pengaruh Penempatan Produk Toyota terhadap Kesadaran Merek pada Film "Nanti Kita Cerita Tentang Hari Ini”
}

\author{
Olivia Nemesis ${ }^{1}$ dan El Chris Natalia ${ }^{2}$ \\ 1, 2 Universitas Katolik Indonesia Atma Jaya, Jakarta, Indonesia
}

\begin{abstract}
ABSTRAK
Penempatan produk (product placement) dapat digunakan sebagai sebuah cara mempromosikan sebuah produk atau jasa. Produk atau jasa ditampilkan sedemikian rupa untuk menimbulkan kesan bahwa produk atau jasa tersebut merupakan bagian dari sebuah film atau program TV. Toyota menampilkan produknya dalam film "Nanti Kita Cerita Tentang Hari Ini". Film "Nanti Kita Cerita Tentang Hari Ini" merupakan sebuah film yang mengangkat tema mengenai keluarga. Penelitian ini bertujuan untuk mengetahui pengaruh penempatan produk Toyota terhadap kesadaran merek (brand awareness) pada film "Nanti Kita Cerita Tentang Hari Ini". Metode penelitian yang digunakan adalah kuantitatif eksplanatif dengan melakukan penyebaran kuesioner secara daring. Hasil penelitian menunjukkan terdapat pengaruh positif antara penempatan produk Toyota terhadap kesadaran merek pada film "Nanti Kita Cerita Tentang Hari Ini". Selain itu, responden juga setuju dapat mengidentifikasi Toyota sebagai perusahaan otomotif dan produk mobil Toyota diperlihatkan tanpa mengganggu fokus responden saat menonton film.
\end{abstract}

Kata kunci: komunikasi pemasaran; penempatan produk; kesadaran merek; film

\begin{abstract}
Product placement can be used as a way to promote a product or service. The product or service is displayed in such a way as to give the impression that the product or service is part of a film or TV program. Toyota displays its products in the film "Nanti Kita Cerita Tentang Hari Ini". "Nanti Kita Cerita Tentang Hari Ini" is a film with the theme of family. This study aims to determine the influence of Toyota's product placement on brand awareness in the film "Nanti Kita Cerita Tentang Hari Ini". The research method used is quantitative explanative by distributing questionnaire online. The results show that there is a positive influence between the product placement of Toyota on brand awareness in the film "Nanti Kita Cerita Tentang Hari Ini". In addition, respondents also agreed that they can identify Toyota as an automotive company and that Toyota's car products are shown without disturbing the respondent's focus while watching the film.
\end{abstract}

Keywords: marketing communication; product placement; brand awareness; film

\section{PENDAHULUAN}

Salah satu cara untuk meningkatkan promosi sebuah produk atau jasa dengan menampilkan produk dengan kesan bahwa keberadaan produk menjadi bagian dari cerita film atau acara TV (Kristanto \& Karina, 2016). Menurut Purnomo (dalam Karimah et al., 2019), penempatan produk (product placement) adalah salah satu cara yang dilakukan oleh rumah produksi film 
guna meringankan biaya produksi film. Penempatan produk sponsor pada film menjadi hal yang menguntungkan bagi kedua belah pihak, karena rumah produksi film mendapat dana dan sponsor dapat menampilkan produk ke sasaran yang tepat.

Penempatan produk dapat menjadi pilihan lain dikarenakan tidak mengganggu audiens. Bahkan, tidak sedikit audiens yang rela membayar lebih untuk menonton film atau program TV tertentu dengan tujuan bebas dari iklan dan ini menjadi nilai tambah untuk penempatan produk. Audiens menonton film atau program TV yang di dalamnya muncul merek barang atau jasa tanpa mengganggu perhatian audiens. Audiens tidak bisa melewatkan atau memblokir penempatan produk pada film atau program TV.

Dikutip dari Global Forecast 2020 (Stamford, 2020), pendapatan dunia dari penempatan produk diharapkan mengalami pertumbuhan di tahun 2021 dan nilai dari intergrasi merek diharapkan meningkat $13,8 \%$ pada kegiatan ekonomi yang lebih kuat, serta tren media yang mendukung hiburan bermerek (branded entertainment). Penempatan produk dapat membantu untuk menunjukkan produk atau jasa termasuk cara pemakaian produk atau jasa tersebut dengan cara yang halus sehingga audiens merasakan bahwa apa yang ditampilkan tersebut adalah bagian dari keseharian pada film atau program TV.

Berdasarkan Tiffany (2019), acara orisinil Netflix yang mendapat pengakuan, penghargaan, dan viral dapat membuka kesempatan bagi merek melakukan penempatan produk. Pelanggan Netflix di Indonesia tercatat sebanyak 16 juta di kuartal pertama dan pada kuartal empat pelanggan penambahan terjadi hingga 8,8 juta. Tidak hanya acara orisinil Netflix yang dapat menikmati efek dari penempatan produk, tetapi film, seperti "Dilan", "Milea", dan "Nanti Kita Cerita Tentang Hari Ini" juga dapat merasakan efek dalam bentuk kesadaran (awareness). Dengan memasukkan produk ke dalam film atau program TV juga dapat meringankan merek mengeluarkan biaya produksi untuk pemasaran yang memerlukan ide kreatif.

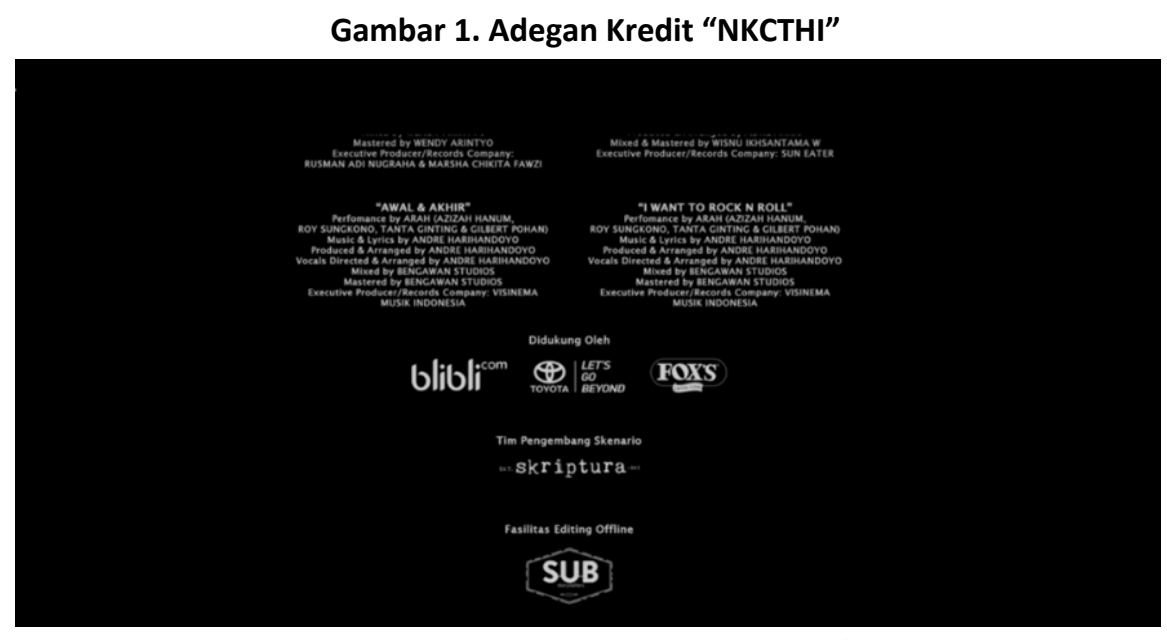

Sumber: Nanti Kita Cerita Tentang Hari Ini (2020) 


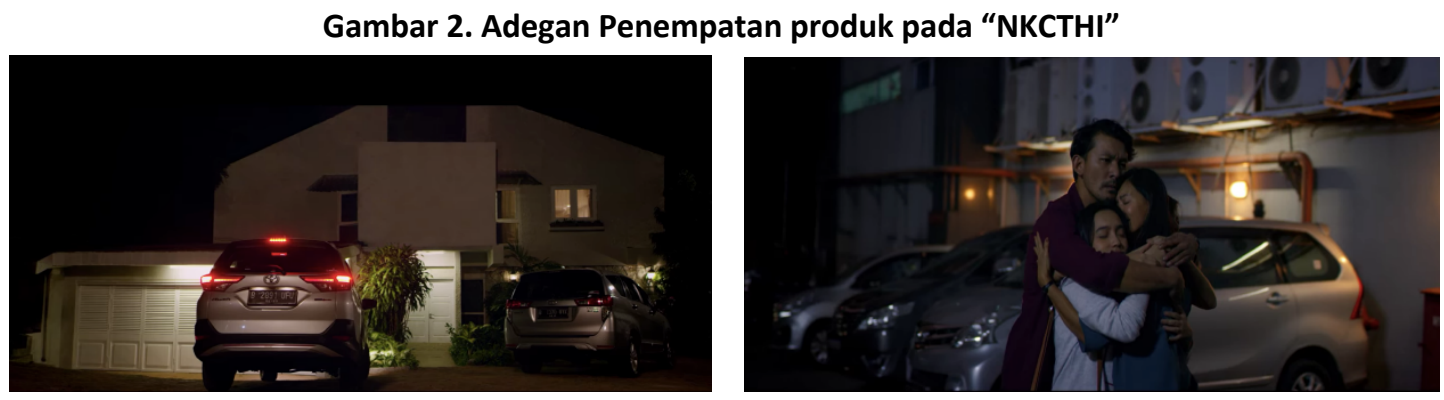

Sumber: Nanti Kita Cerita Tentang Hari Ini (2020)

Penempatan produk terlihat pada film "Nanti Kita Cerita Tentang Hari Ini" (NKCTHI). Beberapa produk Toyota yang digunakan dalam film "Nanti Kita Cerita Tentang Hari Ini" adalah Toyota Starlet 1998, Toyota Kijang Kapsul 2000, Toyota Kijang Innova 2018, dan Toyota Rush 2018. Menurut Yonas (2019), Toyota Indonesia bekerja sama dengan Film “Nanti Kita Cerita Tentang Hari Ini". Diadaptasi dari buku karya Marchella FP dengan judul yang sama, Film "Nanti Kita Cerita Tentang Hari Ini" menceritakan kisah mengenai tiga saudara, yaitu Angkasa, Aurora, dan Awan yang tinggal dalam keluarga yang harmonis. Merek Toyota menempatkan logo dan produk merek di beberapa adegan di Film "Nanti Kita Cerita Tentang Hari Ini". Logo dan produk ditunjukkan secara perlahan dan halus dengan tujuan untuk tidak menghilangkan fokus penonton terhadap plot cerita.

Peneliti menggunakan beberapa penelitian terdahulu sebagai rujukan untuk penelitian ini. Penelitian pertama berjudul "Pengaruh Product Placement terhadap Brand Awareness BMW pada Film 'Mission Impossible: Fallout'" (Steven \& Sudrajat, 2019). Penelitian ini berfokus pada penempatan produk dengan menggunakan dimensi visual placement dan plot connection dan kesadaran merek yang menggunakan dimensi top of mind, brand recognition, brang recall, dan unaware of brand. Hasil penelitian menunjukkan bahwa terdapat pengaruh positif dan signifikan antara penempatan produk terhadap kesadaran merek BMW pada film "Mission Impossible: Fallout". Penelitian lainnya adalah penelitian mengenai "Influence of Product Placements in Films and Television on Consumers Brand Awareness" (Kumar, 2017). Penelitian ini bertujuan untuk mengetahui alasan orang terhubung dengan produk, sikap mereka terhadap penempatan produk dan bagaimana sikap ini mempengaruhi kesadaran merek dan pembelian mereka. Pengumpulan data dilakukan melalui kuesioner yang mencakup pertanyaan tentang opini umum serta pengaruh penempatan produk terhadap kesadaran merek. Hasil penelitian menunjukkan bahwa penempatan produk memiliki potensi besar untuk mempengaruhi pemirsa, dan pemasar perlu mengadopsi strategi untuk membuatnya penggunaan penempatan produk secara optimal, yang pada akhirnya akan meningkatkan penjualan perusahaan. Melihat dari dua penelitian terdahulu tersebut, penelitian ini memiliki kesamaan, yaitu berfokus pada penempatan produk (product placement) dan kesadaran merek (brand awareness). Perbedaannya adalah penelitian pertama melakukan analisis pada film "Mission Impossible: Fallout" dan merek yang dibahas 
adalah BMW. Pada penelitian kedua, fokus penelitian ditujukan pada film dan program televisi.

Berlandaskan latar belakang masalah tersebut, maka permasalahan yang dirumuskan dalam penelitian ini adalah "apakah penempatan produk Toyota memiliki pengaruh dalam meningkatkan kesadaran merek pada Film 'Nanti Kita Cerita Tentang Hari Ini'?”. Penelitian ini bertujuan untuk mengetahui pengaruh penempatan produk Toyota dalam meningkatkan kesadaran merek pada Film "Nanti Kita Cerita Tentang Hari Ini".

\section{Komunikasi Pemasaran}

Komunikasi pemasaran adalah usaha pertama untuk menginformasikan, mempersuasi, dan mengingatkan konsumen secara langsung atau tidak langsung mengenai merek yang dipasarkan (Kotler et al., 2009). Copley (2014), komunikasi pemasaran dapat dijelaskan sebagai bentuk komunikasi yang bersangkutan dengan pemasaran dan dalam arti tertentu merupakan suara dari merek yang ingin berkomunikasi dengan konsumen.

Perusahaan perlu menggunakan strategi promosi dengan jelas dan persuasif untuk mengomunikasikan nilai dari sebuah produk. Idealnya, perusahaan akan melakukan promosi dengan menggabungkan beberapa cara dan mengkoordinasi elemen tersebut agar dapat menghasilkan pesan yang jelas, konsisten, dan menarik mengenai sebuah organisasi atau merek (Kotler \& Armstrong, 2017). Copley (2014) menjelaskan bahwa komunikasi pemasaran dilihat oleh banyak orang sebagai campuran beberapa bagian dari bauran pemasaran dalam cara yang strategis. Konsep pemasaran biasanya disebut dengan singkatan $4 \mathrm{P}$, yaitu product (produk), place (tempat), price (harga), dan promotion (promosi).

\section{Penempatan Produk (Product Placement)}

Dikutip dari American Federal Trade Commission (Powell et al., 2009 dalam Kramolis \& Kopeckova, 2013), penempatan produk diartikan sebagai bentuk promosi dengan menampilkan produk dalam program TV oleh pemasar dengan bayaran tertentu atau pertimbangan lain. Menurut Russel dan Belch (dalam Afiff et al., 2014), penempatan produk adalah penggabungan suatu merek ke dalam sarana hiburan, yang dapat menyediakan pemasar media yang lebih luas.

Penempatan produk diterapkan karena memiliki kepercayaan yang sama dengan iklan, menimbulkan kesadaran, meningkatkan minat, meningkatkan keinginan membeli, dan perubahan perilaku tetapi dengan perspektif yang berbeda (Guennemann \& Cho, 2014). Pandangan penonton terhadap produk atau sikap konsumen terhadap produk dapat dipengaruhi secara positif melalui penempatan produk (Hudson dan Hudson dalam Kramolis \& Kopeckova, 2013). Gambar visual dan penyatuan atas jalan cerita hiburan akan membuat penempatan produk kemungkinan yang lebih berhasil dalam menghasilkan keefektifan dalam brand recall (Lord \& Gupta dalam Afiff et al., 2014). 
Penempatan produk dapat dikategorikan ke dalam beberapa kriteria dan dalam bentuk audiovisual yang sering memberikan efek kepada konsumen (Kramolis \& Kopeckova, 2013). Contohnya adalah pada film, program TV, novel, lagu, dan video game. Menurut Russell (dalam Subianti \& Hudrasyah, 2013), terdapat 3 dimensi kerangka dari karakteristik penempatan produk.

Pertama, visual or screen placement, produk yang diletakkan pada latar belakang sebuah adegan. Level dari penempatan visual dapat berubah sebagai fungsi atas banyaknya produk terlihat atau tidak terlihat sama sekali. Pemasar percaya bahwa penayangan produk berulang kali dapat meningkatkan pengakuan konsumen.

Kedua, auditory or verbal nature of placement, merek bisa saja tidak disebut sama sekali dalam dialog, disebutkan beberapa kali, atau disebutkan dengan tekanan. Pengaruh penempatan pendengaran tergantung pada tiga faktor yang dikutip dari Kristanto \& Brahmana (2016), yaitu: (a) the context in which the brand is mentioned atau konteks penyebutan merek; (b) the frequency that the brand is mentioned atau frekuensi penyebutan merek; dan (c) the emphasis placed on the brand name, penekanan ketika penyebutan merek.

Ketiga, plot connection or congruent, sejauh mana produk berhubungan dengan plot cerita. Dimensi penempatan yang paling sering dilakukan karena dinilai sangat efektif yang memiliki dampak besar dalam mengkomunikasikan merek.

Menurut Belch dan Belch (Steven \& Sudrajat, 2019; Subianti \& Hudrasyah, 2013), terdapat keuntungan atas penempatan produk, antara lain karena penempatan produk didukung oleh media lain, maka produk dapat baik secara langsung maupun tidak langsung dipromosikan oleh beberapa media yang berbeda. Hal ini memberikan kesempatan untuk promosi produk sampai ke target pasar. Produk yang dipasarkan oleh selebriti dalam sebuah program, walaupun hanya dipegang dapat memengaruhi konsumen. Pemilihan film untuk penempatan produk dipilih oleh pemasar dengan target penonton yang sesuai dengan target produk atau merek sehingga pemasar langsung menargetkan produk kepada potensi konsumen.

\section{Kesadaran Merek (Brand Awareness)}

Hubungan positif antara konsumen dengan merek hanya akan ada dengan kesadaran, pengalaman, dan kepercayaan (Lee et al., 2015). O'Guinn, Allen, \& Semenik, (dalam Świtała et al., 2018) menyatakan bahwa kesadaran merek sangat berhubungan dengan kekuatan kehadiran dan jejak sebuah merek yang ada di benak konsumen dan menghasilkan kemampuan untuk mengenali sebuah merek dalam berbagai kondisi pasar. Menurut Urbanek (dalam Świtała et al., 2018), kesadaran merek dapat dikatakan sebagai suatu faktor penting dalam menetapkan kekuatan dan keunggulan merek. Kesadaran merek adalah aset yang dapat mempengaruhi persepsi, presferensi, dan sikap konsumen, serta dapat berdampak 
pada keputusan pembelian mengenai merek yang pada akhirnya akan menambah kesetiaan (Aaker 2015, Mathew 2014 dalam Putri et al., 2019).

Berdasarkan Aaker (dalam Glanfield, 2018), kemampuan pembeli dalam mengenali atau mengingat sebuah merek tertentu dinamakan sebagai kesadaran merek. Kesadaran merek adalah dasar untuk membangun ekuitas merek. Kesadaran merek menurut Aaker (dalam Kristanto \& Karina, 2016) memiliki beberapa level untuk mengukur kesadaran konsumen: (1) top of mind (pikiran teratas), pada level ini konsumen mengingat sebuah merek dari merekmerek lainnya yang ada dalam kategori sama; (2) brand recall (mengingat merek), konsumen dapat mengingat merek tanpa bantuan atau secara langsung pada level brand recall. (3) brand recognition (pengenalan merek), pada tingkatan ini konsumen dapat mengidentifikasi merek setelah dibantu untuk mengingat merek tersebut; dan (4) unaware of brand (tidak mengetahui merek), dalam hal ini konsumen tidak mengenali merek.

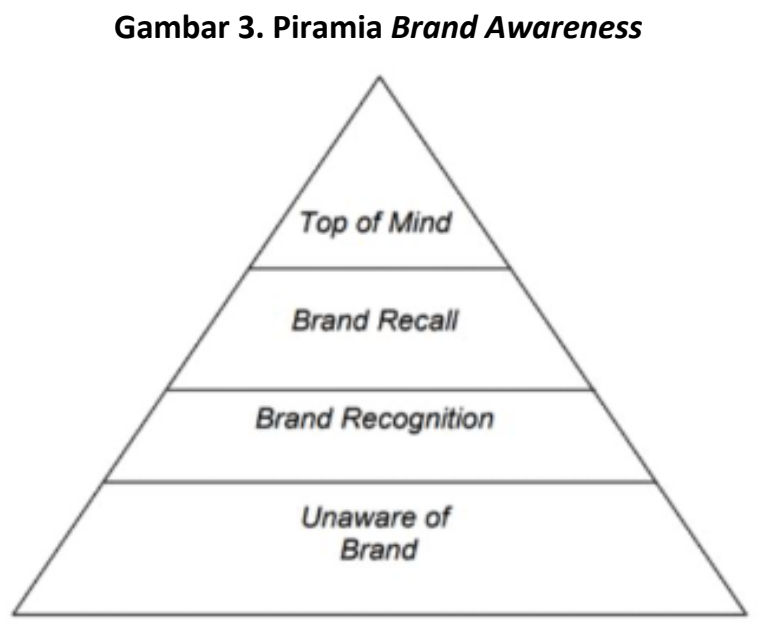

Sumber: Kristanto \& Karina (2016)

\section{METODOLOGI PENELITIAN}

Metode yang digunakan dalam penelitian ini adalah kuantitatif. Penelitian kuantitatif merupakan tipe penelitian yang menghasilkan temuan baru yang dapat diperoleh dari prosedur statistika atau cara-cara lain dengan kuantifikasi dan pengukuran (Jaya, 2020). Penelitian kuantitatif menyederhanakan kompleksitas dari topik ke dalam hitungan yang dapat dihitung. Penelitian kuantitatif ini menggunakan metode kuantitatif eksplanatif. Tujuan dari penelitian kuantitatif eksplanatif adalah untuk melakukan pengujian kepada teori atau konsep dalam riset. Hasil penelitian kemudian akan menunjukkan dua hasil yaitu antara menguatkan teori atau konsep dengan pembuktian yang kuat atau menolak teori atau konsep yang diuji (Rakhmawati, 2019). 
Pada penelitian ini terdapat dua variabel penelitian, yaitu variabel bebas (independent) dan variabel terikat (dependent). Variabel bebas dalam penelitian ini merupakan penempatan produk Toyota pada film "Nanti Kita Cerita Tentang Hari Ini". Pada variabel penempatan produk, dimensi auditory or verbal nature of placement tidak diikutsertakan dalam penelitian karena pada film "NKCTHI" tidak terdapat dialog yang menyebutkan mengenai merek Toyota. Pada film ini juga tidak terdapat faktor konteks, frekuensi, dan penekanan penyebutan merek. Dimensi kerangka dari karakteristik penempatan produk yang diteliti, yaitu: (1) visual or screen placement, penempatan produk di latar belakang sebuah adegan pada film Nanti Kita Cerita Tentang Hari Ini" dan (2) plot connection or congruent, hubungan antara produk dengan plot cerita pada film Nanti Kita Cerita Tentang Hari Ini".

Variabel terikat dalam penelitian ini merupakan kesadaran merek Toyota yang dapat diukur: (1) top of mind, level yang menunujukkan para penonton film "Nanti Kita Cerita Tentang Hari Ini" mengingat Toyota sebagai merek pertama yang diingat ketika ingin membeli mobil atau mengingat merek mobil; (2) brand recall, level ini menunjukkan bahwa para penonton film "Nanti Kita Cerita Tentang Hari Ini" dapat mengingat merek Toyota tanpa bantuan atau secara langsung; (3) brand recognition, level ini memperlihatkan bahwa para penonton film "Nanti Kita Cerita Tentang Hari Ini" dapat mengingat merek Toyota setelah dibantu untuk mengingat merek tersebut; dan (4) unaware of brand, level ini memperlihatkan bahwa para penonton film “Nanti Kita Cerita Tentang Hari Ini” tidak menyadari adanya merek Toyota dalam film.

Populasi dalam penelitian ini adalah seluruh penonton film "Nanti Kita Cerita Tentang Hari Ini", yang menonton baik di bioskop maupun Netflix. Penelitian ini menggunakan teknik sampel purposif atau purposive sampling digunakan karena terdapat karakteristik khusus untuk tujuan menganalisis data (Budiastuti \& Bandur, 2018). Hipotesis penelitian ini adalah:

$\mathrm{H}_{0}$ : Tidak ada pengaruh penempatan produk Toyota pada film "Nanti Kita Cerita Tentang Hari Ini" terhadap kesadaran merek.

$\mathrm{H}_{1}$ : $\quad$ Ada pengaruh penempatan produk Toyota pada film “Nanti Kita Cerita Tentang Hari Ini" terhadap kesadaran merek.

Berdasarkan perhitungan dari rumus sample size using the formula for the standard error of the proportion (Malhotra et al., 2016), maka diperoleh hasil 96. Hasil tersebut menunjukkan bahwa jumlah sampel yang dibutuhkan pada penelitian ini adalah sebanyak 96 responden. Penelitian ini menggunakan teknik survei untuk mengumpulkan data dengan menggunakan survei daring, yaitu Google Form. Selain itu, pada penelitian ini juga dilakukan uji validitas dan reliabilitas dengan hasil seperti pada tabel di bawah ini. 
Tabel 1. Uji Validitas

\begin{tabular}{|c|c|c|c|c|c|}
\hline Variabel & Dimensi & Indikator & $\begin{array}{l}\text { Hasil R } \\
\text { Hitung }\end{array}$ & R Tabel & Keterangan \\
\hline \multirow{7}{*}{$\begin{array}{c}\text { Penempatan } \\
\text { produk }\end{array}$} & \multirow{4}{*}{$\begin{array}{c}\text { Visual or } \\
\text { Screen } \\
\text { Placement }\end{array}$} & 1 & 0,806 & 0,361 & Valid \\
\hline & & 2 & 0,818 & 0,361 & Valid \\
\hline & & 3 & 0,760 & 0,361 & Valid \\
\hline & & 4 & 0,679 & 0,361 & Valid \\
\hline & \multirow{3}{*}{$\begin{array}{c}\text { Plot } \\
\text { Connection or } \\
\text { Congruent }\end{array}$} & 1 & 0,759 & 0,361 & Valid \\
\hline & & 2 & 0,798 & 0,361 & Valid \\
\hline & & 3 & 0,634 & 0,361 & Valid \\
\hline \multirow{6}{*}{$\begin{array}{l}\text { Kesadaran } \\
\text { merek }\end{array}$} & \multirow{3}{*}{$\begin{array}{c}\text { Brand } \\
\text { Recognition }\end{array}$} & 1 & 0,782 & 0,361 & Valid \\
\hline & & 2 & 0,809 & 0,361 & Valid \\
\hline & & 3 & 0,813 & 0,361 & Valid \\
\hline & \multirow[t]{3}{*}{ Brand Recall } & 1 & 0,746 & 0,361 & Valid \\
\hline & & 2 & 0,783 & 0,361 & Valid \\
\hline & & 3 & 0,833 & 0,361 & Valid \\
\hline
\end{tabular}

Sumber: Data olahan peneliti

Tabel 2. Uji Reliabilitas

\begin{tabular}{|c|c|c|}
\hline Variabel & Alpha's Cronbach & Kesimpulan \\
\hline Kesadaran merek & 0,902 & Reliabel \\
\hline Penempatan produk & 0,880 & Reliabel \\
\hline
\end{tabular}

Sumber: Data olahan peneliti

\section{HASIL DAN PEMBAHASAN}

Pada tabel 3, data sampel berasal dari populasi berdistribusi normal dan ditarik kesimpulan dengan membandingkan nilai sig. P-Value dan taraf signifikansi 0,05. Apabila nilai sig. $>0,05$ maka dikatakan normal dan berlaku sebaliknya. Oleh karena itu dapat disimpulkan dari tabel di atas dengan nilai sig. 0,200 >0,05 data terdistribusi normal. Berdasarkan gambar 4, dapat disimpulkan bahwa data terdistribusi secara merata pada diagram P-Plot, karena titik searah dengan garis diagonal dan tidak menyebar sekitar garis diagonal. 
Tabel 3. Uji Normalitas

One-Sample Kolmogorov-Smirnov Test

\begin{tabular}{|c|c|c|c|c|c|}
\hline & & & $X$ & $Y$ & $\begin{array}{c}\text { Unstandardized } \\
\text { Residual }\end{array}$ \\
\hline $\mathrm{N}$ & & & 85 & 85 & 85 \\
\hline \multirow[t]{2}{*}{${ }_{b}^{\text {Normal Parameters }}{ }^{a}$} & \multicolumn{2}{|l|}{ Mean } & 23.65 & 20.35 & .0000000 \\
\hline & \multicolumn{2}{|l|}{ Std. Deviation } & 3.401 & 3.104 & 2.39938390 \\
\hline \multirow{3}{*}{$\begin{array}{l}\text { Most Extreme } \\
\text { Differences }\end{array}$} & \multicolumn{2}{|l|}{ Absolute } & .120 & .121 & .069 \\
\hline & \multicolumn{2}{|l|}{ Positive } & .100 & .120 & .055 \\
\hline & \multicolumn{2}{|l|}{ Negative } & -.120 & -.121 & -.069 \\
\hline \multicolumn{3}{|l|}{ Test Statistic } & .120 & .121 & .069 \\
\hline \multicolumn{3}{|l|}{ Asymp. Sig. $\left(2\right.$-tailed) ${ }^{c}$} & .004 & .004 & $.200^{\mathrm{e}}$ \\
\hline \multirow{3}{*}{$\begin{array}{l}\text { Monte Carlo Sig. (2- } \\
\text { tailed) }{ }^{d}\end{array}$} & Sig. & & .004 & .003 & .410 \\
\hline & \multirow[t]{2}{*}{$\begin{array}{l}\text { 99\% Confidence } \\
\text { Interval }\end{array}$} & $\begin{array}{l}\text { Lower } \\
\text { Bound }\end{array}$ & .002 & .002 & .398 \\
\hline & & $\begin{array}{l}\text { Upper } \\
\text { Bound }\end{array}$ & .005 & .005 & .423 \\
\hline
\end{tabular}

a. Test distribution is Normal.

b. Calculated from data.

c. Lilliefors Significance Correction.

d. Lilliefors' method based on 10000 Monte Carlo samples with starting seed 926214481.

e. This is a lower bound of the true significance.

Sumber: Data olahan peneliti

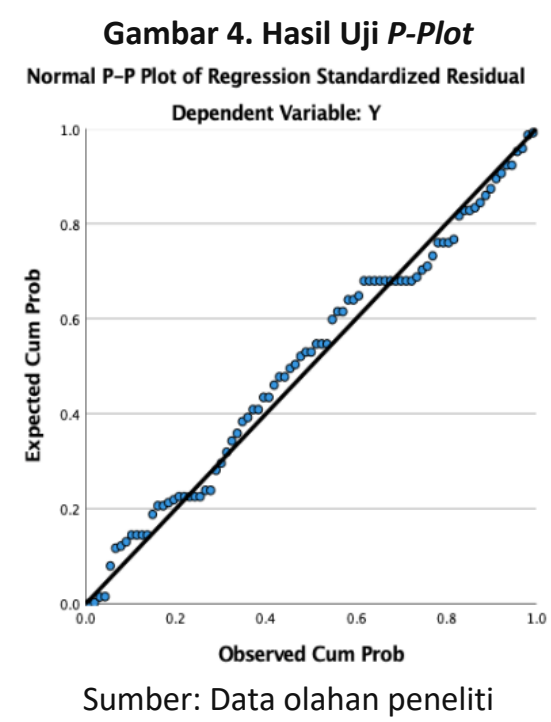

Berdasarkan hasil penghitungan mean score dan overall mean score pada variabel $X$ (penempatan produk) di tabel 4 , pada dimensi visual or screen placement responden sangat 
setuju dengan pernyataan produk diperlihatkan dalam adegan film "NKCTHI" dengan hasil mean score sebesar 3,54. Pada dimensi plot connection or congruent responden sangat setuju dengan pernyataan produk diperlihatkan tanpa mengganggu fokus penonton saat menonton dengan hasil mean score sebesar 3,58. Hasil overall mean score variabel $X$ adalah 3,37 dengan keterangan sangat setuju.

Tabel 4. Analisis Mean Score dan Overall Mean Score pada Variabel X - Penempatan Produk

\begin{tabular}{|c|c|c|c|}
\hline Kode & Pertanyaan & $\begin{array}{l}\text { Mean } \\
\text { Score }\end{array}$ & Keterangan \\
\hline \multicolumn{4}{|c|}{ Dimensi - Visual or Screen Placement } \\
\hline V.1 & $\begin{array}{l}\text { Produk ditempatkan di latar belakang adegan film } \\
\text { "NKCTHI". }\end{array}$ & 3.17 & Setuju \\
\hline V.2 & $\begin{array}{l}\text { Produk dipakai sebagai properti untuk mendukung } \\
\text { adegan film "NKCTHI". }\end{array}$ & 3.44 & Sangat Setuju \\
\hline V.3 & Produk diperlihatkan dalam adegan film "NKCTHI". & 3.54 & Sangat Setuju \\
\hline V.4 & Logo diperlihatkan dalam adegan film "NKCTHI". & 3.41 & Sangat Setuju \\
\hline \multicolumn{2}{|r|}{ Mean Score Visual or Screen Placement } & 3,39 & Sangat Setuju \\
\hline \multicolumn{4}{|c|}{ Dimensi - Plot Connection or Congruent } \\
\hline P.1 & $\begin{array}{l}\text { Produk digunakan untuk melengkapi adegan film } \\
\text { "NKCTHI". }\end{array}$ & 3,45 & Sangat Setuju \\
\hline P.2 & $\begin{array}{l}\text { Produk digunakan karena adanya keterkaitan dengan } \\
\text { adegan film "NKCTHI". }\end{array}$ & 3,02 & Setuju \\
\hline P.3 & $\begin{array}{l}\text { Produk diperlihatkan tanpa mengganggu fokus } \\
\text { penonton saat menonton. }\end{array}$ & 3,58 & Sangat Setuju \\
\hline \multicolumn{2}{|r|}{ Mean Score Plot Connection or Congurent } & 3,35 & Sangat Setuju \\
\hline & Overall Mean Score & 3,37 & Sangat Setuju \\
\hline
\end{tabular}

Sumber: Data olahan peneliti

Tabel 5. Analisis Mean Score dan Overall Mean Score pada Variabel Y - Kesadaran Merek

\begin{tabular}{|c|c|c|c|}
\hline Kode & Pertanyaan & $\begin{array}{l}\text { Mean } \\
\text { Score }\end{array}$ & Keterangan \\
\hline \multicolumn{4}{|c|}{ Dimensi - Brand Recall } \\
\hline B.1 & $\begin{array}{l}\text { Responden dapat mengidentifikasi Toyota sebagai } \\
\text { perusahaan otomotif. }\end{array}$ & 3,65 & Sangat Setuju \\
\hline B.2 & $\begin{array}{l}\text { Responden dapat langsung mengidentifikasi logo } \\
\text { Toyota. }\end{array}$ & 3,63 & Sangat Setuju \\
\hline B.3 & $\begin{array}{l}\text { Ketika melihat produk mobil, responden dapat } \\
\text { langsung mengidentifikasi Toyota. }\end{array}$ & 3,36 & Sangat Setuju \\
\hline & Mean Score Brand Recall & 3,55 & Sangat Setuju \\
\hline \multicolumn{4}{|c|}{ Dimensi - Brand Recognition } \\
\hline
\end{tabular}




\begin{tabular}{|c|l|c|l|}
\hline B1.1 & $\begin{array}{l}\text { Adegan pada film “NKCTHI” membantu responden } \\
\text { mengenali produk Toyota. }\end{array}$ & 3,05 & Setuju \\
\hline B1.2 & $\begin{array}{l}\text { Adegan pada film “NKCTHI” membantu responden } \\
\text { mengenali logo Toyota. }\end{array}$ & 3,2 & Setuju \\
\hline B1.3 & $\begin{array}{l}\text { Adegan pada film “NKCTHI” membantu responden } \\
\text { mengenali Toyota sebagai mobil yang cocok } \\
\text { digunakan untuk keluarga. }\end{array}$ & 3,43 & Sangat Setuju \\
\hline \multicolumn{2}{|}{ Mean Score Brand Recognition } & 3,23 & Setuju \\
\hline Overall Mean Score & 3,39 & Sangat Setuju \\
\hline
\end{tabular}

Sumber: Data olahan peneliti

Hasil analisis mean score dan overall mean score variabel $Y$ (kesadaran merek) pada tabel 5 dimulai dengan dimensi brand recall, responden sangat setuju pada pernyataan bahwa responden dapat mengidentifikasi Toyota sebagai perusahaan otomotif dengan hasil mean score sebesar 3,65. Lalu pada dimensi brand recognition responden sangat setuju dengan pernyataan bahwa adegan pada film "NKCTHI" membantu responden mengenali Toyota sebagai mobil yang cocok digunakan untuk keluarga dengan hasil mean score sebesar 3,43. Hasil overall mean score pada dimensi $Y$ diperoleh sebesar 3,39 dengan keterangan sangat setuju.

Tabel 6. Koefisiensi Determinasi

\begin{tabular}{l|l|r|r|r}
\hline \multicolumn{7}{c}{} & \multicolumn{1}{c}{ Model Summary } \\
\multicolumn{1}{c|}{ Model } & $\boldsymbol{R}$ & $\boldsymbol{R}$ Square & $\begin{array}{r}\text { Adjusted } \\
\boldsymbol{R} \text { Square }\end{array}$ & $\begin{array}{r}\text { Std. Error of } \\
\text { the Estimate }\end{array}$ \\
\hline 1 & $.634^{\mathrm{a}}$ & .403 & .395 & 2.414 \\
\hline a. Predictors: (Constant), X \\
b. Dependent Variable: $Y$ \\
\hline \multicolumn{4}{c}{ Sumber: Data Olahan peneliti }
\end{tabular}

Tabel 6 mengenai koefisien determinasi di atas menunjukkan dari 85 responden (yang menyadari merek Toyota pada film "NKCTHI"), terdapat korelasi (R) antara variabel X dengan Y. Koefisien korelasi $(R)$ menujukkan hasil 0.634 sehingga dapat disimpulkan terdapat korelasi antara penempatan produk dengan kesadaran merek. Berdasarkan interval korelasi, nilai 0,600-0,800 tergolong kuat. Maka artinya, variabel penempatan produk $(X)$ memiliki hubungan yang kuat dengan variabel kesadaran merek $(\mathrm{Y})$.

Berdasarkan tabel 6 juga diketahui bahwa nilai $R$ square adalah 0.403 atau 40,3\%. Maka, dapat disimpulkan bahwa variabel $X$ yaitu penempatan produk mampu menjelaskan variabel $Y$ yaitu kesadaran merek sebesar $40,3 \%$. Sisanya, yaitu sebesar $59,7 \%$ dijelaskan oleh faktorfaktor lain yang tidak dibahas pada penelitian ini. 
Tabel 7. Regresi Linier Sederhana

\begin{tabular}{|c|c|c|c|c|c|c|}
\hline \multicolumn{7}{|c|}{ Model Summary ${ }^{b}$} \\
\hline \multicolumn{2}{|c|}{ Model } & $\begin{array}{c}\text { Unstandardized } \\
\text { B }\end{array}$ & $\begin{array}{l}\text { Coefficients } \\
\text { Std. Error }\end{array}$ & $\begin{array}{c}\text { Standardized } \\
\text { Coefficients Beta }\end{array}$ & $t$ & Sig. \\
\hline \multirow[t]{2}{*}{1} & (Constant) & 6.658 & 1.850 & & 3.599 & $<.001$ \\
\hline & $x$ & .579 & .077 & .634 & 7.478 & $<.001$ \\
\hline
\end{tabular}

Sumber: Data olahan peneliti

Hasil uji regresi linier sederhana diinterpretasikan dengan menggunakan rumus:

$$
\begin{gathered}
\hat{Y}=a+b x \\
\hat{Y}=6,658+0,579 X
\end{gathered}
$$

Berdasarkan tabel 8, a = konstanta bernilai 6,658. Artinya, jika tidak ada penempatan produk (X) maka nilai kesadaran merek (Y) adalah sebesar 6,658. Kemudian, $b=$ konstanta regresi sebesar 0,579. Artinya, setiap penambahan $1 \%$ tingkat penempatan produk (X) maka kesadaran merek $(\mathrm{Y})$ akan meningkat sebesar 0,579. Kemudian, untuk melihat uji hipotesis diterima atau ditolak, peneliti menggunakan nilai sig. dan uji t.

Pada hasil uji regresi linier sederhana, diketahui bahwa nilai t hitung variabel penempatan produk $(X)$ pada tabel 5.24 sebesar 7,478 , dengan menggunakan tingkat signifikasi ( $=5 \%$ atau 0,05 . Untuk menentukan nilai t tabel yaitu dengan $\mathrm{df}=\mathrm{n}-2$ maka $\mathrm{df}=85-2=83$, maka nilai tabelnya adalah 1,988 dengan $t$ hitung sebesar 7,478 dan t tabel sebesar 1,988. Berdasarkan hal tersebut, dapat disimpulkan $\mathrm{t}$ hitung $>\mathrm{t}$ tabel. Oleh karena itu, $\mathrm{H} 1$ diterima dan $\mathrm{HO}$ ditolak. Dengan kata lain, terdapat pengaruh penempatan produk (X) pada film "Nanti Kita Cerita Tentang Hari Ini" terhadap kesadaran merek (Y) Toyota.

Penelitian ini melihat pengaruh yang diberikan strategi penempatan produk Toyota dalam meningkatkan kesadaran merek pada film "Nanti Kita Cerita Tentang Hari Ini". Toyota di Indonesia didirikan pada 2 April 1971 dan berkantor pusat di Sunter II, Jakarta. Film "Nanti Kita Cerita Tentang Hari Ini" tembus 2.256.707 penonton pada hari ke-42 penayangan dan rilis di Netflix pada 23 Mei 2020 dan kuesioner disebar pada Januari 2021. Film "Nanti Kita Cerita Tentang Hari Ini" hadir di bioskop pada 2 Januari 2020, dimana karantina wilayah dimulai pada 30 Maret 2020. Jadi, kuesioner disebarkan ke responden yang menonton film ini, baik di bioskop maupun Netflix.

Berdasarkan data yang telah diolah peneliti, kuesioner tersebar kepada 96 responden yang di antaranya terdapat 21 (22\%) responden merupakan pria dan 75 (78\%) merupakan wanita. Responden terbagi ke dalam beberapa karakteristik usia, domisili, pekerjaan, media 
menonton, terakhir kali menonton, dan durasi menonton. Responden didominasi dengan rentang usia 21-25 tahun, dengan domisili sebagian besar responden di Jakarta dan Tangerang Selatan. Mayoritas merupakan pelajar dan sebagian besar responden menonton film di bioskop. Mayoritas responden menonton film pada Januari 2020, sebagian besar menonton sebanyak 1 kali.

Berdasarkan hasil kuesioner, dari durasi responden menonton film "Nanti Kita Cerita Tentang Hari Ini" menunjukkan bahwa dari 85 responden yang menonton film satu kali terdapat 7 responden yang tidak ingat dengan varian mobil yang ditampilkan. Bagi responden yang menonton film dua kali, terdapat 3 responden yang tidak mengingat varian mobil yang ditampilkan. Bagi responden yang menonton empat kali, terdapat 1 responden yang tidak ingat dengan varian mobil yang ditampilkan. Jumlah responden hanya 85 karena hanya 85 responden dari 96 yang menyadari keberadaan Toyota pada film "Nanti Kita Cerita Tentang Hari Ini".

Hasil kuesioner menunjukkan bahwa dari 85 responden menyadari keberadaan Toyota pada film "Nanti Kita Cerita Tentang Hari Ini" dengan menjawab terdapat Avanza, Yaris, Rush, Innova, dan lain-lain sebagai varian mobil yang ditampilkan. Terdapat 35 responden yang menjawab Kijang Innova sebagai varian mobil yang ditampilkan pada film. Terdapat 19 responden yang menjawab Rush, 11 responden menjawab Avanza, dan 9 responden yang menjawab Yaris sebagai varian mobil yang ditampilkan pada film. 11 responden lainnya menjawab Terios, Xtrail, Calya, dan Fortuner sebagai varian mobil yang ditampilkan pada film.

Berdasarkan hasil kuesioner, dari 85 responden yang menyadari keberadaan Toyota pada film "Nanti Kita Cerita Tentang Hari Ini" terdapat dua responden yang dapat mengidentifikasi 4 varian mobil yang ditampilkan yaitu Toyota Starlet, Toyota Kijang Kapsul, Toyota Kijang Innova, dan Toyota Rush. Terdapat dua responden yang dapat mengidentifikasi 3 varian mobil yang ditampilkan yaitu Toyota Kijang Kapsul, Toyota Kijang Innova, dan Toyota Rush. Terdapat lima responden yang dapat mengidentifikasi 2 varian mobil yang ditampilkan yaitu Toyota Kijang Innova dan Toyota Rush. Terdapat satu responden yang dapat mengidentifikasi 2 varian mobil yang ditampilkan yaitu Toyota Kijang Kapsul dan Toyota Kijang Innova.

Terdapat 11 dari 96 responden yang tidak menyadari keberadaan Toyota pada film "Nanti Kita Cerita Tentang Hari Ini" diberikan pertanyaan tambahan mengenai merek yang kira-kira cocok untuk film "Nanti Kita Cerita Tentang Hari Ini". Sebagian besar responden, yaitu 7 responden menjawab bahwa Toyota cocok digunakan sebagai mobil pada film. Selain itu terdapat 4 dari 11 responden menjawab bahwa Honda cocok digunakan sebagai mobil pada film.

Berdasarkan data yang telah diolah dari kuesioner, menujukkan pada dimensi visual or screen placement mayoritas responden menjawab sangat setuju. Maka, dapat disimpulkan bahwa 
responden merasakan adanya visual or screen placement atau penempatan visual produk Toyota pada film "Nanti Kita Cerita Tentang Hari Ini". Pada pernyataan dimensi plot connection or congruent mayoritas responden menjawab sangat setuju. Oleh karena itu, dapat disimpulkan bahwa responden merasakan adanya plot connection or congruent atau keselarasan plot dengan produk Toyota pada film "Nanti Kita Cerita Tentang Hari Ini”.

Pada kesadaran merek $(\mathrm{Y})$ peneliti mengukur level kesadaran merek yang terdiri dari top of mind, brand recall, brand recognition, dan unaware of brand. Pada dimensi top of mind, terdapat 96 responden dengan 91 responden menjawab Toyota sebagai brand mobil yang ada di film "Nanti Kita Cerita Tentang Hari Ini", sesuai dengan topik penelitian. Selain itu, terdapat satu responden menjawab Honda dan empat responden tidak ingat dengan merek yang diperlihatkan dalam film "Nanti Kita Cerita Tentang Hari Ini".

Dimensi brand recall dan brand recognition diolah dengan 85 responden yang menyadari keberadaan Toyota pada film "Nanti Kita Cerita Tentang Hari Ini". Pada dimensi brand recall, mayoritas responden menjawab sangat setuju. Oleh karena itu dapat disimpulkan bahwa responden dapat langsung mengidentifikasi Toyota. Pada dimensi brand recognition, mayoritas responden menjawab setuju. Maka dapat disimpulkan bahwa adegan film "Nanti Kita Cerita Tentang Hari Ini" membantu responden mengenali Toyota. Pada dimensi unaware of brand, jumlah responden yang mengisi kuesioner ada 96 responden dan mayoritas menjawab mengetahui merek dan logo mobil di film "Nanti Kita Cerita Tentang Hari Ini".

\section{SIMPULAN DAN SARAN}

Berdasarkan hasil analisis yang sudah dijabarkan oleh peneliti, terdapat beberapa kesimpulan. Pertama, berdasarkan hasil penelitian, terdapat pengaruh antara penempatan produk pada film "Nanti Kita Cerita Tentang Hari Ini" terhadap kesadaran merek Toyota. Kedua, dapat disimpulkan bahwa pernyataan yang paling banyak disetujui dalam penelitian ini adalah responden dapat mengidentifikasi Toyota sebagai perusahaan otomotif, dari kesadaran merek dimensi brand recall. Pernyataan yang paling banyak disetujui dari penempatan produk adalah produk mobil Toyota diperlihatkan tanpa mengganggu fokus responden saat menonton film "Nanti Kita Cerita Tentang Hari Ini" pada dimensi plot connection or congurent placement. Selain itu, dari hasil penelitian juga terdapat korelasi antara penempatan produk dengan kesadaran merek dengan nilai koefisien korelasi 0,634. Hasil korelasi 0,634 dapat diinterpretasikan sebagai hubungan korelasi yang kuat antara penempatan produk dengan kesadaran merek.

Peneliti juga memberikan beberapa saran dari sisi akademis dan praktis, yaitu peneliti menyarankan perlu adanya penelitian lebih lanjut terutama pada variabel penempatan produk. Pada penelitian ini dimensi auditory or verbal nature of placement tidak dapat diteliti 
karena dimensi tidak dipakai dalam film "Nanti Kita Cerita Tentang Hari Ini”. Maka, akan lebih baik apabila untuk penelitian berikutnya dalam meneliti penempatan produk dapat menggunakan dimensi yang lengkap agar hasil penelitian lebih mendalam hasil kajiannya. Peneliti juga menyarankan untuk melakukan penelitian selanjutnya dengan menggunakan metode kualitatif. Metode kualitatif dapat menjelaskan secara mendalam mengenai dimensi pada penempatan produk dan kesadaran merek dengan pengumpulan data melalui wawancara, observasi, dan lain-lain.

Pada saran praktis, hasil penelitian menunjukkan terdapat pengaruh penempatan produk terhadap kesadaran merek, sehingga Toyota dapat menggunakan metode penempatan produk di masa depan ke berbagai film yang cocok dengan merek Toyota. Dari 96 responden, hanya 85 responden yang menyadari keberadaan Toyota pada film "Nanti Kita Cerita Tentang Hari Ini". Maka akan lebih baik apabila penempatan produk dilakukan dengan lebih eksplisit. Pihak Toyota disarankan untuk dapat memunculkan visual logo atau produk lebih lama dan menggunakan seluruh dimensi, yaitu dengan auditory or verbal nature of placement agar penonton bisa lebih menyadari keberadaan merek Toyota dalam film. Berdasarkan hasil penelitian, pengaruh penempatan produk terhadap kesadaran merek mendapatkan respon yang positif. Oleh karena itu, peneliti menyarankan bagi Toyota untuk mempertahankan dan meningkatkan strategi dalam komunikasi pemasaran. 


\section{DAFTAR PUSTAKA}

Budiastuti, D. \& Bandur, A. (2018). VALIDITAS DAN RELIABILITAS PENELITIAN. Penerbit Mitra Wacana Media.

Copley, P. (2014). Marketing Communications Management: Analysis, Planning, Implementation. SAGE Publications. http://dx.doi.org/10.4135/9781473909632

Karimah, K. E., Syafitri, P. I. E., \& Wahyudin, U. (2019). Etika praktik product placement dalam film Ayat-Ayat Cinta 2. Jurnal Manajemen Komunikasi, 4(1), 60. https://doi.org/10.24198/jmk.v4i1.23478

Glanfield, K. (2018). Brand Transformation: Transforming Firm Performance by Disruptive, Pragmatic and Achievable Brand Strategy. Routledge. https://doi.org/10.4324/9781315160450

Guennemann, F. \& Cho, Y. C. (2014). The Effectiveness of Product Placement by Media Types: Impact of Image and Intention to Purchase. Journal of Service Science, 7(1), 29-42. https://doi.org/10.19030/jss.v7i1.8911

Jaya, I. M. L. M. (2020). Metode Penelitian Kuantitatif dan Kualitatif: Teori, Penerapan, dan Riset Nyata. ANAK HEBAT INDONESIA.

Kotler, P. \& Armstrong, G. (2017). Principles of Marketing an Asian Perspective Fourth (4th Ed.). Pearson Education Limited.

Kotler, P., Keller, K., Brady, M., Goodman, M., \& Hansen, T. (2009). Marketing Management. Prentice Hall.

Kramolis, J. \& Kopeckova, M. (2013). Product Placement: A Smart Marketing Tool Shifting a Company to the Next Competitive Level. Journal of Competitiveness, 5(4), 98-114. https://doi.org/10.7441/joc.2013.04.06

Kristanto, H. \& Brahmana, R. K. M. R. (2016). Pengaruh Product Placement Pada Film Indonesia Terhadap Brand Awareness Dan Purchase Intention Masyarakat Surabaya. Jurnal Manajemen Pemasaran, 10(1), 20-26. https://doi.org/10.9744/pemasaran.10.1.20-26

Kumar, S. (2017). Influence of Product Placements in Films and Television on consumers Brand Awareness. Archives of Business Research, 5(2). https://doi.org/10.14738/abr.52.2747 
Lee, A., Yang, J., Mizerski, R., \& Lambert, C. (2015). The Strategy of Global Branding and Brand Equity. Routledge.

Malhotra, N. K., Nunan, D., \& Birks, D. F. (2016). Marketing research. In M. Baker \& S. Hart (Eds.), The Marketing Book (7th ed., pp. 161-190). Pearson Education Limited. https://doi.org/10.4324/9781315890005

Putri, A. D. E., Indarini, \& Anandya, D. (2019). The influence of brand communication, brand image, brand satisfaction, and brand trust on brand loyalty. Advances in Social Science, Education and Humanities Research, 308, 122-125. https://doi.org/10.2991/insyma19.2019.31

Rakhmawati, Y. (2019). Buku Ajar Metode Penelitian Komunikasi. Putra Media Nusantara.

Sasongko, A. D. (Director). (2020). Nanti Kita Cerita Tentang Hari Ini [Film]. Visinema Pictures.

Stamford, C. (2020, Mei 27). Global Product Placement Spend Up 14.5\% to \$20.6B in 2019, But COVID-19 Impact to End 10-Yr Growth Streak in 2020; Strong Rebound Seen in '21 on TV, Digital, Music Growth. CISION PRWeb. https://www.prweb.com/releases/global_product_placement_spend_up_14_5_to_ 20_6b_in_2019_but_covid_19_impact_to_end_10_yr_growth_streak_in_2020_stro ng_rebound_seen_in_21_on_tv_digital_music_growth/prweb17146134.htm

Steven, S. \& Sudrajat, R. H. (2019). PENGARUH PRODUCT PLACEMENT TERHADAP BRAND AWARENESS "BMW" PADA FILM MISSION IMPOSSIBIE: FALLOUT. Scriptura, 8(2), 7582. https://doi.org/10.9744/scriptura.8.2.75-82

Subianti, T. \& Hudrasyah, H. (2013). Analysis of movies product placement and its effect towards the audience case study: Ayat-Ayat Cinta, Perahu Kertas, Habibie \& Ainun movie. Journal of Buiness and Management, 2(2), 163-189.

Świtała, M., Gamrot, W., Reformat, B., \& Bilińska-Reformat, K. (2018). The influence of brand awareness and brand image on brand equity - an empirical study of logistics service providers. Journal of Economics and Management, 33(3), 96-119. https://doi.org/10.22367/jem.2018.33.06

Tiffany, H. (2019, Desember 16). Netflix Is Ad Free, but It Isn't Brand Free. The New York Times. https://www.nytimes.com/2019/12/16/business/media/netflix-commercials.html 
Viane, C., Dundu, B. A. K. T., \& Mandagi, R. J. M. (2016). PENGARUH PENDAYAGUNAAN SUMBER DAYA MANUSIA (TENAGA KERJA) TERHADAP HASIL PEKERJAAN (STUDI KASUS PERUMAHAN TAMAN MAPANGET RAYA(TAMARA)). Jurnal Sipil Statik, 4(1), 1320.

Yonas, A. R. (2019, Oktober 2019). Kerja Sama dengan Toyota Indonesia, NKCTHI Web Series Bakal Tayang Sebelum Film Rilis. Tribunnewswiki.com. https://www.tribunnewswiki.com/2019/10/22/kerja-sama-dengan-toyotaindonesia-nkcthi-web-series-tayang-lebih-dulu-dari-filmnya 